EASTERN REVIEW 2017, T. 6

\author{
Mirostaw Karwat
}

\title{
Uczestnictwo i poczucie uczestnictwa. Analiza pojęć
}

Problematyka partycypacji (obywateli w życiu politycznym, pracowników w zarządzaniu przedsiębiorstwem, mieszkańców w funkcjonowaniu miasta itp.) to w istocie cały kompleks problemów: Co to znaczy: uczestniczyć? W czym możemy uczestniczyć? Jakie są możliwe formy i przejawy uczestnictwa? Od czego zależy możliwość lub niemożliwość uczestnictwa lub taki czy inny zakres uczestnictwa? Jakie czynniki obiektywnie - niezależnie od naszej świadomości i woli - czynią nas uczestnikami? Jakie czynniki sprzyjają uczestnictwu, a jakie stają się barierami, przeszkodami? Co sprawia, że pojawia się, utrzymuje, wzmacnia lub słabnie, zanika gotowość do uczestnictwa? Jakie pobudki skłaniają ludzi do uczestnictwa aktywnego? Na co liczą ci, którzy decydują się na aktywność, wywieranie wpływu, okazywanie oporu? Kiedy ludzie obiektywnie uczestniczący mają poczucie uczestnictwa lub są go pozbawieni; i od czego to zależy? A to i tak niepełna lista pytań. Bo też samo zjawisko nazywane partycypacją (synonimicznie - uczestnictwem) jest syndromem wielu zjawisk i mechanizmów, a nie fenomenem jednowymiarowym.

Jednak nad badaniami partycypacji zwykle ciąży albo potoczne (uproszczone lub banalne) rozumienie uczestnictwa, albo w każdym razie brak głębszej refleksji nad sensem tego pojęcia, brak odwołania do abstrakcyjnej, ogólnej teorii uczestnictwa, ukazującej uniwersalnie typową morfologię i mechanizm uczestnictwa w czymkolwiek ${ }^{1}$. W nielicznych odniesieniach do samego pojęcia uczestnictwa ${ }^{2}$ lub próbach teorii uczestnictwa nie zawsze oddzielone są ujęcia analityczne od normatywnych i postulatywnych ${ }^{3}$. Bardziej wyrafinowani badacze przyjmują in-

${ }^{1}$ Wyjątki są nieliczne. Zob. B. Misztal, Zagadnienia społecznego uczestnictwa i współdziałania. Analiza w świetle teorii i badań socjologicznych, Wrocław 1977; D. Mider, Partycypacja polityczna w internecie. Studium politologiczne, Warszawa 2008.

2 Por. Z.J. Zdybicka, Analiza pojęcia partycypacji występującego w filozofii klasycznej, „Roczniki Filozoficzne. Filozofia Teoretyczna” 1970, t. XVIII, z. 1.

${ }^{3}$ Przykładem aksjonormatywnego ujęcia uczestnictwa (w tym wypadku - z perspektywy postulatów aksjologicznych personalizmu) jest traktat: K. Wojtyła, Osoba i czyn oraz inne studia an- 
tencjonalne zawężenia tego pojęcia, na ogół jednak bez komentarza odnoszącego się do kontekstu i do aspektów zjawiska pomijanych w przyjętej definicji regulacyjnej albo wręcz perswazyjnej.

Wiedza o uwarunkowaniach i barierach partycypacji, o możliwych sposobach i formach ,animacji”, aktywizacji, mobilizacji społecznej obywateli pozostanie wycinkowa i - wbrew socjotechnicznemu zaprogramowaniu - mało skuteczna, jeśli nie wysilimy się na całościowe, a nie fragmentaryczne ujęcie tego zjawiska. Wymaga to namysłu nad jego złożoną strukturą i różnymi kategoriami determinant. A najpierw uwolnienia się od pojęciowych uproszczeń.

\section{Popularne uproszczenia w rozumieniu słowa "uczestnictwo"}

Uproszczeniem „specjalistycznym”, ale jednak uproszczeniem, i to zabarwionym potocznie, jest przyzwyczajenie wielu politologów lub socjologów polityki (nie mówiąc już o dziennikarzach), by partycypacją polityczną nazywać uczestnictwo w wyborach, ewentualnie jeszcze w demonstracjach, akcjach protestacyjnych - i nic więcej. Jak gdyby uczestnictwo w polityce ograniczało się do odświętnych, cyklicznych lub okazjonalnych aktów mobilizacji.

Nieco mniejszym uproszczeniem - dominującym jednak w literaturze politologicznej i w publicystyce politycznej - jest, zwykle niewypowiadane wprost, założenie, iż partycypacja polityczna to przypadłość tych, którzy należą do partii politycznych (lub są co najmniej aktywnymi zwolennikami i sympatykami), jako ich członkowie i działacze włączają się do pewnych kampanii lub powszedniego rytmu funkcjonowania (zebrania, konsultacje, dyskusje, kolportaż materiałów propagandowych i agitacyjnych, praca nad dokumentami programowymi itp.). Wtedy bierzemy pod uwagę kryterium zainteresowania sprawami państwa, aktywności, ewentualnie zaangażowania ideologicznego. Ale też z tego względu wyłączamy z zakresu tego terminu tych, którzy polityką interesują się sporadycznie i wyrywkowo, zaś sami nie podejmują aktywności partyjnej czy obywatelskiej. A tym bardziej tych, którzy polityką się nie interesują, swoją intencję apolityczności uznają za fakt. Politolog nie powinien jednak brać za dobrą monetę subiektywnych wyobrażeń i wręcz złudzeń potocznych, lecz kierować się systemową analizą złożonych współzależności między funkcjonowaniem społeczeństwa i państwa a świadomością i aktywnością lub biernością jednostek (obywateli) i całych środowisk. Wszak to, że ktoś nie interesuje się polityką, nie znaczy bynajmniej, iż polityka go nie dotyczy, co więcej, iż nie jest - choćby nieświadomym, bezwiednym - współsprawcą wydarzeń i zmian politycznych, narzędziem

tropologiczne, Lublin 2000. Zob. też: E. Podrez, Moralne uzasadnienie tolerancji. Studium z etyki personalistycznej, Warszawa 1999, rozdz. 2. 
takich czy innych sił politycznych, beneficjentem lub ofiarą określonych rozwiązań prawnych, decyzji, zasad podziału dóbr.

W obiegowych ,kratocentrycznych” interpretacjach polityki rola kręgów rządzących, elit politycznych, zawodowych polityków, administratorów, menedżerów, ideologów itd. w polityce w ogóle i w szczególności w sprawowaniu władzy jest traktowana jako na tyle oczywista, że nie określa się jej jako uczestnictwo; choć - paradoksalnie - właśnie elity i ,aparaty” uznaje się za jedynych naturalnych uczestników polityki, gry politycznej, walki politycznej ${ }^{4}$. Wtedy termin „partycypacja” odnoszony jest głównie lub wyłącznie do pozostałych grup społeczeństwa, do tych, którzy sami bezpośrednio nie panują, nie rządzą, nie decydują, choć usiłują wywrzeć wpływ na rządzących ${ }^{5}$. Polityka, rządzenie, walka o władzę traktowane są jako domena (w rezultacie, niezależnie od intencji autorów, również jako przywilej) tych, którzy zawodowo zajmują się polityką, a w tylko nieco szerszym ujęciu, gdyby sparafrazować M. Webera ${ }^{6}$, którzy żyją polityką (pasjonaci), dla polityki i z polityki. Logiczną implikacją takiego rozwiązania terminologiczno-pojęciowego jest wniosek - daleki od demokratycznych deklaracji teoretyków czy samych polityków - iż uczestnictwo w polityce to „włączanie się” w życie polityczne, w rezultacie dopuszczenia lub nawet zachęty do uczestnictwa ze strony rządzących.

W tym ujęciu termin ,partycypacja” (uczestnictwo) jest traktowany jako dopełnienie takich pojęć, jak „,władza”, ,rządzenie”, ,podejmowanie decyzji”; jako termin pochodny, a nie wyjściowy i nadrzędny w stosunku do nich. Tymczasem realistyczne i systemowe podejście uzmysławia nam, że trudno nie nazwać polityka (a nie tylko kandydata, pretendenta do tej roli) uczestnikiem polityki, a rządzenie nie jest jedyną formą wpływu politycznego.

Kuszącym uproszczeniem, które jednak stale nęci politologów i rozmaitych analityków, komentatorów, jest kolejny „aksjomat”, także nie wypowiadany wprost i nieuzasadniany z powodu poczucia (pozornej) oczywistości, że uczestnictwo (w polityce lub w ogóle w życiu społecznym) nie dotyczy jednostek i grup społecznych wyłączonych z głównego nurtu (np. zmarginalizowanych lub dyskryminowanych), a tym bardziej formalnie pozbawionych praw i wykluczonych. Jak gdyby ich upośledzony status był równoznaczny z tym, że - pomijając aspiracje i oczekiwania takich grup lub stan apatii - nie wywierają one żadnego wpływu na stosunki społeczne i ściśle polityczne w danym państwie. Tu znów widać, jak zwodnicze, a naukowo bezproduktywne jest traktowanie kwalifika-

\footnotetext{
${ }^{4}$ Niewątpliwie trafne jest rozróżnienie kratocentrycznej oraz socjocentrycznej perspektywy w interpretacjach polityki, wyłożone w artykule: M. Gulczyński, Alternatywne orientacje w politologii, „Wyższa Szkoła Ekonomiczna. Zeszyty Naukowe” 2009, nr 1(54).

5 Przykład: bardzo pożyteczna poza tym publikacja: Partycypacja. Przewodnik krytyki politycznej, Warszawa 2012.

${ }^{6}$ M. Weber, Polityka jako zawód i powołanie, Kraków 1998.
} 
cji normatywnych (prawnych, obyczajowych) jako dosłownych i pełnych charakterystyk statusu politycznego różnych grup społecznych. Wszak grupy zmarginalizowane, zgettoizowane co najmniej absorbują swoim położeniem grupy funkcjonujące $\mathrm{w}$ głównym nurcie życia społecznego, podmioty polityki i organy władzy; a fenomen radykalizacji, ekstremizmu i terroryzmu we współczesnych społeczeństwach ujawnia, właśnie jako skutek marginalizacji, paradoksalny - destrukcyjny, antysystemowy - typ uczestnictwa, ale jednak uczestnictwa. Pełne spektrum uczestnictwa obejmuje zarówno uczestników przystosowanych i wręcz afirmujących dany porządek społeczny, jak i uczestników nieprzystosowanych oraz kontestujących ${ }^{7}$. Na tej zasadzie opozycja antysystemowa tak czy inaczej jest uczestnikiem życia politycznego w reżymie politycznym, który usiłuje podważyć i zastąpić innym.

Do katalogu takich uproszczeń, zubażających nasze myślenie i badania, dorzućmy jeszcze jedno: również pozornie oczywiste założenie, że uczestnikiem można być tylko pozostając elementem danej całości, funkcjonując wewnątrz niej na zasadzie przynależności i spełniania określonej funkcji. Otóż niezupełnie. W grze politycznej w danym państwie jak najbardziej uczestniczą siły zewnętrzne. Przykład: infiltrowana i rozgrywana przez ingerencję sąsiednich mocarstw Polska przedrozbiorowa; a współcześnie: wpływ na życie polityczne takiego czy innego państwa ze strony przedstawicielstw dyplomatycznych i służb wywiadowczych obcych państw, korporacji międzynarodowych, zagranicznych i transnarodowych imperiów medialnych. Analogicznie - w stosunkach rodzinno-małżeńskich: kochanka męża lub kochanek żony mogą w istotny sposób (także rozmyślnie i aktywnie) wpływać na więzi małżeńskie i rodzinne - na ich charakter i klimat psychiczno-moralny; podobnie - byli małżonkowie na funkcjonowanie męża lub żony w nowym małżeństwie, ze względu na aspiracje i uprawnienia do opieki nad dziećmi, rozliczenia finansowe i majątkowe itd. Uczestnikiem jest więc nie tylko insider; może nim być również outsider (i ten dosłownie rozumiany, z zewnątrz danego państwa, i ten metaforycznie tak określany ze względu na marginalizację, dyskryminację lub „odbieganie od normy”) ${ }^{8}$.

Wreszcie, do popularnych i wciąż zaraźliwych uproszczeń w rozumieniu uczestnictwa należy zasugerowanie subiektywnymi wyobrażeniami ludzi obiektywnie współtworzących daną całość społeczną. Poczucie nieuczestnictwa (subiektywne wyobrażenie, iż - wbrew rzeczywistemu stanowi rzeczy - nie należy się do danej wspólnoty; poczucie wyobcowania z danego środowiska, społeczeństwa, marginalizacji, wykluczenia itd.) nie zmienia faktu bycia uczestnikiem; to

7 Zob. K. Obuchowski, Adaptacja twórcza, Warszawa 1985; fragment pt. Typy uczestnictwa w zmianach społeczno-ekonomicznych.

${ }^{8}$ Por. na ten temat: H.S. Becker, Outsiderzy. Studia z socjologii dewiacji, Warszawa 2009; Uczenie się od outsidera. Perspektywa europejskiej wspótpracy edukacyjnej, red. J. Rutkowiak, Kraków 1997. 
określa jedynie rodzaj i zakres uczestnictwa. Podobnie - postawa obojętności wobec problemów społecznych, sporów ideowych i pragmatycznych. I podobnie - odmowa uczestnictwa (np. bojkot), a także sprzeciw, protest, kontestacja, programowe zwalczanie ustroju (przez dysydentów, wywrotowców czy rewolucjonistów) lub państwa jako takiego (przez separatystów lub zewnętrznych dywersantów). Bunt i zwalczanie danego układu społecznego „od środka” można co najwyżej nazwać ,przeciwuczestnictwem”. Przeciwnik wewnętrzny, obywatel zniewolony i co najmniej wewnętrznie zbuntowany, emigrant wewnętrzny także jest uczestnikiem życia politycznego w swoim kraju, choć w innej formie i w innym stopniu niż obywatele nastawieni afirmatywnie lub lojalistycznie, pełnoprawni i „konstruktywnie” aktywni.

Uznając podobne zawężenia pojęciowe za oczywistość, przestajemy rozumieć, że w rzeczywistości uczestnikami polityki są wszyscy ci, których projekty, decyzje i konflikty polityczne dotyczą, wpływając na ich własną sytuację, interesy, a bezpośrednio na ich nastroje i opinie; a których nawet „,apolityczne” (w intencjach czy w formalnym charakterze) zainteresowania, dążenia i zachowania wpływają na układ sił politycznych, na legitymizację lub delegitymizację rządów, a nawet ustroju politycznego jako takiego.

Za podstawę do adekwatnej definicji terminu „uczestnictwo" (partycypacja) trzeba przyjąć realny fakt obecności w danej przestrzeni społecznej, wpływania na stosunki społeczne w danym społeczeństwie czy społeczności już samą tą obecnością, współzależność między sytuacją socjoekonomiczną, samopoczuciem i szansami samorealizacji grup o nietożsamych (rozbieżnych lub nawet sprzecznych) interesach partykularnych, ale też ich wspólne uzależnienie od danej wspólnoty, jej konsolidacji lub dezintegracji, bezpieczeństwa, integralności i suwerenności ${ }^{9}$.

\section{Intencjonalne i konwencjonalne zawężenia pojęcia}

Czym innym niż potoczne lub w każdym razie bezrefleksyjne obiegowe uproszczenia są konwencje terminologiczno-pojęciowe związane z określoną intencją poznawczą - z zamiarem skupienia uwagi na jakimś aspekcie zjawiska i podkreślenia jego wagi. Wówczas terminowi „uczestnictwo” przypisujemy znaczenie zawężone (a nie wspomniane wyżej kompleksowe, syndromatyczne) w trybie definicji regulacyjnej lub konstrukcyjnej. Niekiedy taka regulacja lub innowacja definicyjna graniczy z definicją perswazyjną, gdyż cechą definicji perswazyjnych jest bądź celowa zmiana zakresu i treści nazwy bądź przypisanie jej określonego znaku wartości (sensu pozytywnego lub pejoratywnego), ładunku

9 Zob. J. Modrzejewski, Socjalizacja i uczestnictwo społeczne. Studium socjopedagogiczne, Poznań 2007; rozdz. II. O typologii społecznego uczestnictwa... 
emocjonalnego ${ }^{10}$. Od uproszczeń potocznych, obiegowych takie zawężenie różni się tym, iż autor i kompetentny użytkownik , ,icencji terminologicznej” pozostaje świadomy, iż badane zjawisko samo w sobie ma bogatszą treść, również inne aspekty niż te wyeksponowane w przyjętym określeniu. Choć kolejni odbiorcy takiego skrótu mogą już nim operować bez tej poprawki.

Przykładem takiego intencjonalnego zawężenia pojęcia uczestnictwa jest termin ,demokracja partycypacyjna”, przyjęty w odróżnieniu od demokracji przedstawicielskiej, w ślad za rozróżnieniem demokracji pośredniej i bezpośredniej ${ }^{11}$. Zakłada się w tej typologii, iż demokracja przedstawicielska to „władza ludu” zapośredniczona przez wybór, a następnie funkcjonowanie reprezentantów, podczas gdy demokracja partycypacyjna opiera się na „włączaniu się" obywateli do procesów decyzyjnych (przykładem - budżet „partycypacyjny”, konsultacje, plebiscyty, referenda), a nawet legislacyjnych, podejmowaniu inicjatyw. I przy tym zakłada się też, iż właśnie takie określenia trafnie charakteryzują specyfikę możliwych modeli demokracji. Jeśli jednak ktoś zbyt dosłownie potraktuje tę terminologię, to zapomni o fakcie, iż wybór przedstawicieli jest uczestnictwem, funkcjonowanie reprezentantów podlega takiej czy innej kontroli (jeśli nie formalnej, to chociażby w funkcjonowaniu opinii publicznej, w akcjach protestacyjnych lub rewindykacyjnych) - co jest uczestnictwem obywateli-wyborców w życiu politycznym, zaś sama działalność przedstawicieli jest niczym innym jak... uczestnictwem. Termin „demokracja partycypacyjna” nie oznacza, iż w ,niepartycypacyjnej” nie ma partycypacji. Odmienny rozkład akcentów jest uzasadniony, lecz rozwiązanie terminologiczne bardzo ułomne.

Inny przykład intencjonalno-konwencjonalnego zawężenia pojęcia to zastosowanie - w podręczniku teorii zarządzania sprzed lat - terminu „uczestnictwo” jako skrótowego określenia tego, co ściślej mówiąc, należałoby nazwać postawą uczestnictwa ${ }^{12}$. Podobne określenie (skrót myślowy) można jednak i dziś spotkać w wielu podręcznikach lub poradnikach menedżerskich, pedagogicznych, socjotechnicznych przeznaczonych dla działaczy społecznych, aktywistów, animatorów kultury, wolontariuszy itd.

Podane wyżej dwa przykłady dotyczą analityczno-opisowego użytku z termi$\mathrm{nu}, \mathrm{tzn}$. jego zastosowania $\mathrm{w}$ badaniach naukowych i w przekazie wiedzy $\mathrm{w}$ celach praktycznych.

A oto przykład intencjonalno-konwencjonalnego zawężenia zakresu terminu w języku normatywnym. Jest nim termin „,współuczestnictwo” rozumiane nie w sensie opisowym jako bycie jednym z uczestników współzależnych i współ-

${ }_{10}$ Zob. T. Pawłowski, Pojęcia i metody wspótczesnej humanistyki, Wrocław 1977; rozdz. V. Definicje perswazyjne.

11 Por. G. Sartori, Teoria demokracji, Warszawa 1994; R. Górski, Bez państwa. Demokracja uczestniczaca w działaniu, Kraków 2007.

12 J. Zieleniewski, Organizacja zespołów ludzkich, Warszawa 1976. 
działających, ale jako możliwość lub obowiązek włączenia się do czegoś, gdy nie musi to być dla nas czymś oczywistym, należnym i powszednim. Taki sens przybrały w praktyce ustrojowej i w modelach zarządzania w niektórych krajach pojęcia współrządzenia, Mitbestimmung, samorządności (pracowniczej lub lokalnej), demokracji społecznej, demokracji pracowniczej itp.

\section{Rewizja aktywistycznego stereotypu uczestnictwa}

Szczególnym przypadkiem intencjonalnego i konwencjonalnego zawężenia sensu terminu „uczestnictwo” jest utożsamienie go z aktywnością społeczną, obywatelską, której atrybutem jest taki czy inny stopień zaangażowania (emocjonalnego, ideowego, refleksyjnego) w życie społeczne, w rozstrzyganie spraw publicznych oraz towarzysząca temu i wyrażająca to działalność społeczna, podejmowanie inicjatyw praktycznych. W tym sensie uczestniczy ktoś, kto interesuje się sprawami społecznymi, ma ambicję wywierania wpływu i gotów jest w tym celu do własnego wysiłku, wkładu. Oto przykład, zresztą, nieco tautologiczny: „Czynny udział i posiadanie wpływu w jakichś, zwłaszcza ważniejszych, dziedzinach życia społecznego"13. W podobnym duchu utrzymana jest koncepcja partycypacji politycznej i odpowiadająca jej konwencja pojęciowa Gerda Meyera ${ }^{14}$.

Tradycyjnie główny nurt badań nad partycypacją polityczną koncentruje się na kwestii, jak i dlaczego ludzie wstępują do partii politycznych, głosują w wyborach, kandydują na stanowiska wybieralne i mianowane, manifestują swoje przekonania, wolę, roszczenia, sprzeciw, względnie, dlaczego powstrzymują się od aktywności i decyzji, odmawiają poparcia, rezygnują z przynależności i obecności. Znajduje to przełożenie na wiele pytań: z jakich pobudek to czynią, pod jakimi warunkami, w jakim zakresie, jakim kosztem i z jakim skutkiem, dobrowolnie czy z przymusu, w imię czego itd. Jest zrozumiałe, że na takich aspektach skupia uwagę np. socjologia wyborcza (choć i tu badając frekwencję wyborczą, analizuje się zarazem skalę i podłoże absencji), empirycznie zorientowana socjologia zachowań politycznych, empiryczna psychologia polityki. Jest to naturalny podział pracy, pod warunkiem, że nie przestajemy widzieć w tych, którzy nie rządzą i nie kandydują, nie przemawiają, nie głosują, nie manifestują, uczestników właśnie - nie tylko potencjalnych, ale i realnych, choć biernych i pośrednich.

Z punktu widzenia zadań poznawczych socjologii polityki i teorii polityki nie wystarczy analiza owych ,ruchomości” (tj. przejawów aktywności ludzkiej). Ambicją badań politologicznych winno być uchwycenie związku między tym,

${ }_{13}$ Stownik katolickiej nauki społecznej, red. ks. W. Piwowarski, Warszawa 1993, s. 183.

${ }_{14}$ Zob. Political Participation and Democracy in Poland and West Germany, eds G. Meyer, F. Ryszka, Warszawa 1991; Introduction autorstwa G. Meyera. 
co dany podmiot „daje z siebie” (co jest jego wkładem, tym bardziej poświęceniem, wyrzeczeniem, stratą, krzywdą) a tym, co „bierze” lub... odbiera innym, poczynając od społecznych kosztów jego „obsługi” w danej roli i społecznych kosztów jego niepowodzeń, nieefektywności, wysiłków chybionych itd. Dopiero wtedy sięgamy głębiej do mechanizmu polityki. Tylko pod tym warunkiem możemy odpowiedzieć na pytania typu ,jak to było możliwe”, „kto jest za to odpowiedzialny”, „kto ma czyste ręce” itd. itp. Odpowiedzieć w kategoriach rzetelności poznawczej, obiektywizmu i dociekliwości, a nie „pod tezę z góry założoną", w kategoriach ideologicznych czy wąskonormatywnych. W szczególności: niezwykle naiwne, jeśli nie obłudne, są przejawy zdziwienia i/lub pretensje polityków nastawionych demokratycznie, pedagogów, a nawet i badaczy kultury politycznej z powodu niedostatecznej aktywności lub całkowitej bierności (indyferentyzmu, a nawet apatii ${ }^{15}$ ) obywateli, jeśli nie odpowiada się na pytania, czy i w czym ludzie aktywni lub bierni są zainteresowani, jakie bariery materialne (dochody, bilans czasu pracy i czasu wolnego), mentalne, obyczajowe i prawne tworzą przeszkody lub zniechęcają do aktywności.

Również w funkcjach doradczych pedagodzy, psycholodzy, socjolodzy i politolodzy okażą się bezproduktywni, jeśli projektując mechanizmy aktywizacji, animacji, mobilizacji społecznej, wzorce społeczeństwa obywatelskiego abstrahować będą od czynników partykularnego zainteresowania lub niezainteresowania w aktywności, czynników socjoekonomicznej selekcji uczestników polityki (kogo stać na luksus niezarobkowej aktywności społecznej; kto ma czas wolny na lektury, przemyślenia, dyskusje, wiece, pochody; kto jest w stanie ponieść koszty powołania do życia i funkcjonowania stowarzyszeń, partii czy mediów), od wpojonego ludziom stylu życia.

\section{Definicja uczestnictwa}

Udaną - bo adekwatną i wyczerpującą - definicję uczestnictwa sformułował dokładnie 40 lat temu polski socjolog Bronisław Misztal: „Przez społeczne uczestnictwo rozumiem takie plasowanie się poszczególnych jednostek i grup jednostek w ramach szerszych całości i bardziej ogólnych społecznych konstelacji, które zakłada:

- jakościowo odrębną i analitycznie odróżnialną cechę przynależności tej jednostki czy grupy jednostek do tej całości czy konstelacji, mierzonej bądź za pomocą zespołu kryteriów obiektywnych (miejsce w sposobie produkcji i podziale pracy, spełniana funkcja, wykonywany zawód, miejsce zamieszkania, wiek itp.)

15 Pogłębioną analizę przejawów i uwarunkowań takich postaw zawiera monografia L. Szczegóła, Bierność obywateli. Apatia polityczna w teorii demokratycznej partycypacji, Warszawa 2013. 
bądź subiektywnych (podzielanie wspólnych poglądów, odznaczanie się pewnymi, rzeczywistymi bądź wyimaginowanymi postawami itp.);

- charakterystyczną i określaną przez normy społeczno-kulturowe pozycję i rolę w tej całości czy konstelacji;

- subiektywnie odczuwaną bądź obiektywnie istniejącą więź społeczną spajającą w pewien sposób uczestników;

- w niektórych przypadkach również formalnie potwierdzone lub zewnętrznie manifestujące się członkostwo"16.

Dalej autor trafnie (choć brzmi to nieco samochwalczo) ocenia walory własnej definicji: „Powyższa definicja odznacza się następującymi cechami ogólnymi: przede wszystkim nie przesądza ona ani nie określa charakteru czy formy tych całości, czy konstelacji; po wtóre, uwzględnia element więzi społecznej, łączącej poszczególnych uczestników, przy czym nie przesądza, czy jest to więź subiektywna (grupa społeczna) czy też zobiektywizowana relacja społeczna (klasa, warstwa); w końcu, definicja ta obejmuje swoim zasięgiem wszelkie typy uczestnictwa, tak sformalizowane jak i nieformalne, tak celowe jak dobrowolne, tak determinowane przez standardy kulturowe, jak i wynikające $z$ organizacyjnych czy asocjacyjnych uwikłań. Jako kryteria obiektywnego członkostwa zastosować można zmienne o charakterze socjologicznym, ekonomicznym, demograficznym, politycznym, przestrzennym, a więc wszelkie cechy, które w toku badawczego postępowania wyjaśniającego dadzą się uchwycić w sposób mniej lub więcej wymierny" 17 .

Trzeba się zgodzić z tą samooceną, ze wskazaniem metodologicznych walorów przytoczonej definicji. Autor unika tu błędu typowego dla rozlicznych, choć zwykle formułowanych ad hoc i kontekstowo, definicji uczestnictwa, w których termin ten przyporządkowuje się jedynie pewnym aspektom, komponentom tego zjawiska (choć w istocie jest ono syndromem zależności, więzi intencjonalnych i uwikłań) i pewnym jego formom rodzajom (np. uczestnictwu świadomemu i zamierzonemu).

Co prawda, definicja Bronisława Misztala odnosi się nie tyle do wszelkiego uczestnictwa (w czymkolwiek), ile - precyzyjnie rzecz ujmując - do uczestnictwa, które nazwałbym strukturalnym. Polega ono na trwałej przynależności jednostek do pewnej wspólnoty (społeczności, grupy społecznej, stowarzyszenia, instytucji - np. zakładu pracy), ewentualnie również na identyfikacji z nią (w takim czy innym stopniu) oraz na takim czy innym stopniu aktywności, służącej z jednej strony zaspokojeniu potrzeb własnych członka (pracownika, mieszkańca, obywatela), z drugiej zaś - realizacji zadań społecznych, wymagań środowiska, obowiązków wobec tej wspólnoty.

${ }^{16}$ B. Misztal, Zagadnienia spolecznego uczestnictwa..., s. 208.

${ }^{17}$ Ibidem, s. 208-209. 
Już nieco inaczej należałoby zdefiniować uczestnictwo w zdarzeniach społecznych, sytuacjach społecznych, wreszcie - w procesach społeczno-historycznych. W nich możemy uczestniczyć nie tylko jako obiektywni lub zaangażowani członkowie określonej całości społecznej, niejako z jej ramienia, w jej imieniu, ale również zupełnie przypadkowo i na własne konto. Tu częściej w grę może wchodzić więź przelotna (nawet jeśli intensywnie przeżywana i nacechowana nie tylko podleganiem oddziaływaniom, ale i sprawstwem), przypadkowa, mimowolna lub nawet nieuświadamiana.

Wspólny mianownik jest jeden: mniej lub bardziej złożona współzależność między całością społeczną a grupą lub jednostką. To znaczy, z jednej strony, takie czy inne uzależnienie części od całości, a z drugiej strony - określony stopień wpływu komponentu na tę całość. Poza tym jednak istotne są różnice, choć i zachowane analogie - właśnie ze względu na schemat relacji „całość - część (składnik)".

Uczestnik zdarzenia czy procesu oczywiście nie jest „członkiem” tego zdarzenia czy procesu. Ma w nim określone miejsce i rolę, lecz określone przecież nie na zasadzie normatywnego wyznaczenia pozycji i powierzenia obowiązków, reprodukcji statusu, ale na zasadzie ,zaszłości”, korelacji i następstwa czynni$\mathrm{ków}^{18}$. W uczestnictwie incydentalnym związek między jednostką (lub grupą) a całością tego, co zaszło, nie jest więzią społeczną, lecz koincydencją, korelacją (tak jest np. ze świadkiem wypadku) lub stosunkiem sprawstwa ${ }^{19}$ (przykłady: błąd kierowcy uruchamiający całą lawinę skutków w otoczeniu; ofiara wypad$\mathrm{ku})$. Uczestnictwo w procesie społeczno-historycznym to diachroniczny związek następstwa (sytuacja i zachowanie jednostki lub grupy jako konsekwencja pewnej sekwencji wydarzeń i zmian społecznych), w jakimś stopniu zakreślający ramy dla podmiotu (co jest nieuchronne, co jest możliwe, co zależy lub nie zależy od jego własnego zamiaru, wyboru i gotowości do takiego czy innego zachowania) ${ }^{20}$.

Jednak, kiedy rozważamy „partycypację polityczną” w kategoriach uregulowanego (zwyczajowo, obyczajowo, prawnie) usytuowania i działania obywateli w życiu publicznym, w funkcjonowaniu państwa, to strukturalne pojęcie uczestnictwa i przytoczona definicja B. Misztala wystarczą. Incydentalne (zdarzeniowe, sytuacyjne) pojęcie uczestnictwa ma inne zastosowanie, podobnie - to procesu-

18 Zob. P. Rybicki, Struktura społecznego świata. Studia z teorii społecznej, Warszawa 1979, s. 134-175; W. Łukaszewski, Szanse rozwoju osobowości, Warszawa 1984, fragment pt. Umiejscowienie w biegu wydarzeń, umiejscowienie w czasie.

19 Analizę mechanizmu sprawstwa i jego konsekwencji zawiera klasyczna rozprawa: Cz. Znamierowski, Wina i odpowiedzialność, Warszawa 1957.

${ }^{20}$ Mechanizm wyznaczania i przekraczania ram społecznych dla funkcjonowania jednostek przedstawia traktat: E. Goffman, Analiza ramowa. Esej z organizacji i doświadczenia, Kraków 2010. Model ten znajduje zastosowanie i do trwałych struktur społecznych, i do ich przekształceń. 
alne. To drugie jest konieczne i użyteczne w analizie genezy i ewolucji ruchów społecznych, inicjatyw obywatelskich, zbiorowych przewartościowań ideowych, wreszcie - przemian ustrojowych. W dalszym wywodzie pozostaniemy przy tym strukturalnym pojęciu uczestnictwa.

\section{Społeczny i podmiotowy sens terminu ,uczestnictwo"}

Pojęcie uczestnictwa odnosi się do złożonej więzi między całością a częścią. Chodzi tu jednak wyłącznie o całość społeczną - taką jak społeczeństwo, naród, wspólnota religijna, społeczność, grupa społeczna, zespół ludzki, stowarzyszenie, instytucja, organ instytucji. Więź między jednostkami lub grupami składowymi a tą całością jest stosunkiem społecznym lub raczej splotem zależności i stosunków społecznych - w odróżnieniu od powiązań np. między podzespołami a maszyną jako całością. Krople deszczu nie uczestniczą w deszczu, choć są jego komponentami. To nie samochód uczestniczy w wypadku, lecz kierowca, obdarzony umiejętnością lub nieumiejętnością jego obsługi, zdolnością lub niezdolnością do przyswojenia sobie zasad ruchu drogowego, zdolnością do prawidłowych decyzji, jak i do błędu, związany obowiązkiem znajomości przepisów i ich respektowania.

Całość społeczna skupia istoty świadome i kierujące się własnymi potrzebami, a nie dosłownie rozumiane śrubki w mechanizmie; choć metaforycznie nazywamy tak jednostki przymusowo lub nawet dobrowolnie ubezwłasnowolnione, całkowicie uprzedmiotowione $\mathrm{w}$ danej instytucji ${ }^{21}$. W odróżnieniu od części maszyn, podzespołów są to podmioty przynajmniej potencjalnie zdolne są uświadomić sobie własną (osobniczą lub grupową) odrębność oraz różnicę i współzależność między własnymi partykularnymi warunkami egzystencji, potrzebami, interesami, dążeniami a wymogami integracji zespołu, instytucji, społeczności, wynikającymi stąd zadaniami, jakie im przypadają w udziale. Określenie „,uczestnictwo" rezerwujemy więc w pierwszej kolejności dla więzi charakterystycznych dla świata ludzkiego - dla mniej lub bardziej uświadamianych relacji między jednostką a grupą, wspólnotą. Choć jest ono adekwatne również w odniesieniu do zachowań społecznych w świecie zwierząt, opartych na komunikacji psychicznej, stosunkach hierarchii, dominacji, kooperacji, rytuałach, odnosi się do odruchów i działań stadnych ${ }^{22}$. I dotyczy również społecznych zachowań zwierząt udomowionych. Wyróżnikiem zachowań społecznych i więzi między ludźmi jest m.in.

${ }^{21}$ Sposób funkcjonowania i myślenia jednostek skrajnie uprzedmiotowionych, zredukowanych do roli „trybiku w machinie”, ale też internalizujących swój status, omówiony jest w książce: M. Karwat, Figuranctwo jako paradoks uczestnictwa. Eseje przewrotne, Warszawa 2004.

${ }^{22}$ Por. E.O. Wilson, Socjobiologia, Poznań 2000. 
kulturowa konwencjonalizacja zachowań i ich interpretacji, abstrakcyjno-symboliczna oprawa więzi i mechanizmów społecznej regulacji zachowań.

Znakomicie, choć pośrednio i kontekstowo, oddaje to Arystotelesowskie spostrzeżenie, iż państwo tworzą istoty zdolne do odróżniania dobra od $\mathrm{zła}^{23}$.

\section{Obiektywny, subiektywny i intersubiektywny wymiar uczestnictwa}

Relacja społeczna między całością społeczną a współtworzącymi ją jednostkami ma kilka aspektów.

Pierwszy z nich to obiektywna zależność między tą całością a jej formalnymi lub nieformalnymi członkami - zależność genetyczna (czego przejawem jest reprodukcja biologiczna, jak i socjalizacja), egzystencjalna (uzależnienie egzystencji jednostek od społecznych mechanizmów wytwarzania i podziału dóbr), strukturalna (miejsce w strukturze danej całości wyznaczone danej jednostce ${ }^{24}$, determinujące i ograniczające jej możliwości), funkcjonalna (przypisane jej role społeczne i konkretne zadania).

Drugi - to moment subiektywny: świadomość bycia częścią czegoś, ocena własnego włączenia czy uwikłania, samookreślenie (w dialektyce indywidualności i typowości, poczucia własnej niepowtarzalności i poczucia przynależności, identyfikacji), wola i gotowość do uczestniczenia lub dysonans między samookreśleniem i poszukiwaniem własnego miejsca a nieakceptowaną przynależnością.

Trzeci aspekt tego zjawiska to więź - obiektywna, jak i psychiczna - między członkami tej wspólnoty, wzajemnie od siebie uzależnionymi ze względu na zaprogramowanie tej całości, ustalony w niej podział pracy, i podobnie zależnymi od całości, do której wspólnie należą. Można by to nazwać intersubiektywnym aspektem uczestnictwa, mając na myśli stosunki wzajemnej percepcji, komunikacji wzajemnej i kooperacji, facylitacji ${ }^{25}$.

Pełnowymiarowe, wyczerpujące ujęcie uczestnictwa (podobnie jak w ogóle więzi społecznych) wymaga rozróżnienia i uwzględnienia w konkretnych charakterystykach wszystkich tych trzech aspektów. Ze zrozumieniem, iż niekoniecznie zachodzi pomiędzy nimi symetria i odpowiedniość. I tak: subiektywne wyobrażenia o przynależności lub aspiracje mogą rozmijać się z faktyczną przynależnością i statusem jednostek; a wspólnota położenia społecznego i losów niekoniecznie

\footnotetext{
${ }^{23}$ Arystoteles, Polityka, Warszawa 1964, s. 7.

${ }^{24}$ A to jest pochodną społecznego podziału pracy, choć nie tylko. Zob. E. Durkheim, O podziale pracy spotecznej, Warszawa 1999.

${ }_{25}$ Zob. Th.M. Newcomb, R.H. Turner, Ph.E. Converse, Psychologia społeczna. Studium interakcji ludzkich, Warszawa 1970, s. 488-493; R. Sennett, Razem. Rytuały, zalety i zasady wspótpracy, Warszawa 2013.
} 
powoduje zespołowe czy zbiorowe poczucie wspólnoty, wzajemną identyfikację i grupową solidarność. Ale tak czy inaczej chcąc zrozumieć jakikolwiek konkretny przypadek uczestnictwa trzeba go rozpatrywać przez pryzmat tych trzech wyznaczników i stopnia ich spójności lub dysonansu.

\section{Bierna i czynna strona uczestnictwa}

Przez uczestnictwo możemy rozumieć: przynależność, bycie elementem jakiejś całości i dopełnieniem w jej ramach dla innych elementów, ale i podleganie oddziaływaniom i wpływom innych, a także własne działanie. Są to nietożsame wymiary więzi z całością i współskładnikami. Odpowiada im również nieidentyczna zależność między tym, co „daję” (wnoszę jako swój wkład) i tym, co „biorę" (otrzymuję lub... odbieram innym). Z tego punktu widzenia należy rozróżniać bierną i czynną stronę uczestnictwa, a sam fenomen uczestnictwa rozpatrywać przez pryzmat proporcji i współzależności między działaniem a podleganiem oddziaływaniom, między „dawaniem” a „braniem”26.

Zaznaczmy dla porządku, że bierna i czynna strona uczestnictwa nie jest tym samym, co bierny (pasywny) lub czynny (aktywny) charakter uczestnictwa, który definiujemy przez stosunek podmiotu do celów działania, obecność własnej woli i inicjatywy itd.

Potoczny stereotyp bierności przesłania nam fakt, iż nawet dosłownie pojęta bierność (choć w czystej postaci to w życiu społecznym rzadkość) także jest uczestnictwem; co więcej, jest odpowiednikiem działania. Podkreślają to prawnicy, gdy mówią, iż zaniechanie także jest działaniem, skoro wywołuje skutki dla nas samych i dla innych.

Ten element z pozoru abstrakcyjnego rozumowania ujawnia swe praktyczne wymiary np. w kontekście denazyfikacji czy destalinizacji, gdy rozliczamy nie tylko inicjatorów i sprawców (bezpośrednich wykonawców) zbrodni, nadużyć, ale i sprawców zaniechań, które to umożliwiły, a także beneficjentów, włącznie z tymi mimowolnymi (przykład: rolnik w III Rzeszy zobowiązany do korzystania z pracy robotników przymusowych ${ }^{27}$.

Najdosłowniej bierny jest nie tyle ten, co „nic nie robi”, ile ten, kto do własnej bezczynności, do narzuconego mu „unieczynnienia” lub do swych czynności

${ }^{26}$ Dwoistość ról społecznych i strategii życiowych akcentowana w literaturze poradnikowej z pogranicza psychotechniki i socjotechniki. Zob. np. A. Grant, Dawaj i bierz, Warszawa 2014; C. Evatt, B. Feld, Dawcy i biorcy, Gdańsk 2001.

${ }^{27}$ Przykładem analizy fenomenu ,zwykli Niemcy jako udziałowcy Trzeciej Rzeszy” jest monografia - co prawda, namiętna, w konwencji pamfletu socjologicznego: D.J. Goldhagen, Gorliwi kaci Hitlera. Zwyczajni Niemcy i Holocaust, Warszawa 1999. 
(np. też narzuconych, wymuszonych) nie ma osobistego stosunku, nie ocenia tego przez pryzmat własnego namysłu, własnej woli, własnego poglądu i interesu ${ }^{28}$.

Termin „bierna i/lub czynna strona uczestnictwa” przyjmujemy tu przez analogię do gramatycznych kwalifikacji czasowników (,maluję” a ,jestem malowany"), choć nie jest to pełna analogia.

Aktywny typ uczestnictwa ma stronę bierną i czynną. „Bierną” stroną aktywności jest to, jakim oddziaływaniom (pobudzającym go zresztą do tej aktywności, ale i tym utrudniającym ją) podlega podmiot - gdyż działając nie tylko działa, ale i podlega cudzym oddziaływaniom, wpływom, naciskom, wymaganiom. „Czynną" stroną aktywności jest i to, jak reaguje na oddziaływania, i to, jak sam je inicjuje.

Bierny typ uczestnictwa także - wbrew pozorom zasugerowanym przez tę nazwę - ma stronę bierną i czynną. Czynną stroną biernego uczestnictwa jest np. to, w jaki sposób uchylamy się od pewnych obowiązków, unikamy zagrożeń, jak swoją biernością właśnie stwarzamy bariery, przeszkody dla cudzych oddziaływań, ale też jak własną biernością (zamiast wysiłków) uzyskujemy określone rezultaty, korzyści lub straty. Obrazowym wcieleniem tego jest postać „wojaka” Szwejka.

Utożsamienie uczestnictwa $\mathrm{z}$ aktywnością, działaniem to pokusa wciąż silna nie tylko w myśleniu potocznym, ale i w myśleniu teoretyków. Powinniśmy jednak wyciągnąć wnioski z oczywistego faktu, iż aby działać w ramach i na rzecz jakiejś całości społecznej, trzeba w niej funkcjonować, co raczej nie jest możliwe samoobsługowo i samowystarczalnie, lecz dzięki mechanizmom dystrybucji dóbr, narzędzi, uprawnień, dzięki wyposażeniu i ,zasilaniu” ze strony środowiska, w jakim się znajdujemy.

Rzadko uzmysławiamy sobie fakt - lub jego konsekwencje - iż ci, którzy „nic nie robią" (np. nie pracują - z różnych powodów, nie głosują w wyborach, nie dokonują zakupów jako konsumenci, lecz korzystają - choćby biernie - z rozmaitych praw i świadczeń), także absorbują energię i zasoby społeczne ${ }^{29}$. I tak, konsument powstrzymujący się od zakupów w pewnym sensie „wymusza” akcje reklamowe i promocyjne, oferty kredytowe, sezonowe wyprzedaże itp. Osoba niepracująca pozostaje na utrzymaniu rodziny lub państwa, korzysta z różnych form pomocy, swoim stanem i kosztem swego utrzymania określa sposób funkcjonowania otoczenia. Osobę niepełnosprawną lub obłożnie chorą „obsługują" i wyręczają w różnych czynnościach (fizycznych, jak i prawnych) jej najbliżsi. Czy przez to nie jest uczestnikiem życia rodzinnego? Wreszcie, ci, którzy nie głosują w wyborach, wbrew pozorom są uczestnikami (choć nie w sensie formalnym) procesu wyborczego, gdyż zabiegi o ich zmobilizowanie wymagają ze

${ }^{28}$ Por. E. Fromm, Rewolucja nadziei. Ku uczłowieczonej technologii, Poznań 1996, s. 35-36, 63-65.

${ }^{29}$ Por. St. Holmes, C.R. Sunstein, Koszt praw. Dlaczego wolność zależy od podatków, Warszawa 2003. 
strony rywalizujących kandydatów podjęcia określonych wysiłków, poniesienia wydatków, zaś określona proporcja między frekwencją i absencją wyborczą w korelacji z rozkładem procentowym głosów oddanych rozstrzyga o wyniku wyborów. Są więc współsprawcami czyjegoś zwycięstwa i czyjejś porażki, określonego układu sił politycznych i stosunku władzy. I nie bez racji powiada im się, jeśli narzekają na wynik i późniejsze skutki wyborów, że trzeba było głosować.

$\mathrm{Z}$ drugiej strony, podmiot o biernej postawie (niezainteresowany i nieumotywowany do aktywności własnymi potrzebami, realizujący wymagania i zadania pod naciskiem, a nawet przymusem) tak czy inaczej spełnia te wymagania i zadania czynnie, przez podejmowanie wysiłków, określonych czynności urzędowych, proceduralnych lub też rytualnych, symbolicznych. Jest to..., ,czynna strona jego bierności”. Z kolei podmiot aktywny (z punktu widzenia własnego zaangażowania - ideowego, emocjonalnego) nie przestaje być obiektem oddziaływań, także takich, które go „ustawiają”, umożliwiają wykorzystanie jego dążeń i wysiłków w celach nawet rozbieżnych i sprzecznych z jego własnymi zamiarami, intencjami, zaś sama jego potrzeba aktywności i gotowość do aktywności może wynikać nie tylko z jego własnych potrzeb i aspiracji, ale również z bodźców zewnętrznych. To niejako „bierna strona jego aktywności”.

\section{Poziomy uczestnictwa}

Specyfika biernej oraz czynnej strony uczestnictwa tudzież współzależność między byciem „biorcą" a byciem „dawcą”, między statusem obiektu oddziaływań a statusem podmiotu ukazuje nam wyraźnie, iż uczestnictwo należy rozpatrywać w kategoriach stopniowania więzi jednostek lub grup ze wspólnotą, do jakiej należą.

Etymologiczna i semantyczna analiza wyrażenia uznawanego za synonim terminu „uczestnictwo” - „brać udział” ujawnia, że określenie to jest wieloznaczne, nawet zwodnicze. W konkretnych sytuacjach i kontekstach może to oznaczać zarówno wnoszenie udziału (nazywanego wtedy wkładem), jak i posiadanie lub otrzymywanie i przyjmowanie udziału, a raczej rozmaitych ,udziałów”. Te dwie relacje różnią się między sobą jakościowo, co wyraża już potoczne skojarzenie z „braniem” i „dawaniem”, ale to skojarzenie nie dość ścisłe. Można otrzymywać, bo przyjmować to, co inni „dają” (np. przydzielają, przyznają, użyczają), ale też „brać” (np. wypracować dla siebie, ale i wywalczyć, a także zawłaszczyć, przywłaszczyć). To, co nam ,przypada w udziale”, może być swoistym odwzajemnieniem tego, co „daliśmy z siebie", wynagrodzeniem lub rekompensatą za podjęte wysiłki, poniesione koszty i straty, jak i trybutem zupełnie nieuzależnionym od naszych działań i ich wyników, przesądzonym już tylko przez samą w sobie przynależność rasową, etniczną, klasową, przez bycie kobietą, mężczyzną, kaleką, dzieckiem. 
Uczestnictwo strukturalne należy więc analizować nie statycznie, ale jako swego rodzaju gradację, stopniowanie włączenia - trochę jak w wojsku: od przydziału do jednostki po awanse i ordery.

Z punktu widzenia jednostki uczestniczyć w życiu społeczeństwa, narodu, państwa, w funkcjonowaniu Kościoła, partii politycznej lub stowarzyszenia to znaczy:

1) być osobowym ogniwem w zorganizowanej całości - ze statusem „składnika instrumentalnego", potencjalnego wykonawcy określonych ról społecznych, funkcji, zadań, obowiązków, podporządkowanego określonym wymaganiom społecznym, normom i wzorcom konstytutywnym dla tej całości; z mniejszą lub większą szansą zaznaczenia swojej obecności, wywarcia wpływu, zaspokojenia własnych potrzeb i aspiracji przy okazji działania na rzecz wspólnoty;

2) odnosić korzyści lub ponosić straty z tytułu samej w sobie przynależności, z powodu bycia częścią całości, członkiem zbiorowości (czego wyrazem na poziomie makrospołecznym są grupowo określone prawa, wręcz przywileje, względnie grupowo zaadresowany pewien zakres i rodzaj upośledzenia społecznego, dyskryminacji, pokrzywdzenia);

3) przyczyniać się własnym funkcjonowaniem lub świadomym działaniem, aktywnością do funkcjonowania całości, do której się należy, w charakterze sprawnego wykonawcy, ale też inicjatora, inspiratora, depozytariusza pewnych wartości (to nazywamy metaforycznie wnoszeniem wkładu) - bądź... działać na szkodę tej całości, pasożytować na niej;

4) odnosić korzyści lub ponosić straty z tytułu działania, wysiłku poniesionego na rzecz lub wbrew interesom danej całości - co prawda, nie tylko i nawet nie tyle ze względu na zasługi lub szkody same w sobie, ile ze względu na społeczną lub czyjąś arbitralną i tendencyjną ocenę tego wkładu.

Rozpatrując to samo z punktu widzenia danej całości, można te cztery poziomy uczestnictwa określić następująco:

1) wyznaczenie miejsca i „zaprogramowanie społeczne” (status społeczny przypisany z góry jednostce, wynikający ze statusu przyznanego danej kategorii lub grupie społecznej - np. klasy, warstwy, grupy etnicznej, rasy, kategorii zawodowej, płci, kategorii wiekowej; miejsce w hierarchii wewnętrznej w danej wspólnocie; narzucane wymagania i oczekiwania, potencjalny zakres praw i obowiązków; zakreślenie kulturowych i prawnych ram dla możliwych form zachowania i działania);

2) otrzymywanie udziału (tzn. praw, przywilejów, dóbr, świadczeń, korzyści i strat, nagród i kar) z tytułu samej w sobie przynależności i miejsca w hierarchii społecznej, a bez względu na własną postawę i wysiłki;

3) wnoszenie wkładu (aktywne i konstruktywne wysiłki, zasługi, osiągnięcia istotne dla interesów i istnienia całości, jak i destruktywny wpływ na funkcjonowanie całości: dywersja, szkodnictwo wynikające z niedbalstwa i niekompetencji, błędów i porażek - absorbujące energię pozostałych uczestników i wymagające kompensacji strat); 
4) otrzymywanie udziału (w postaci nagród i kar, przywilejów, uznania lub napiętnowania społecznego) z tytułu wniesionego wkładu (skoro wkład może mieć charakter zarówno pozytywny, konstruktywny, jak i negatywny, destrukcyjny, a może być - i najczęściej bywa - problematyczny, sporny lub np. niewymierny).

Ten abstrakcyjny, modelowy schemat znajduje konkretne zastosowanie w analizie sytuacji i kolei życiowych obywatela, wyborcy, podatnika, żołnierza, ucznia, nauczyciela.

Przy tym prawidłowością, a co najmniej regułą statystyczną wydaje się być niewspółmierność między wniesionym wkładem a otrzymanym udziałem - np. przecenienie lub niedocenienie wkładu, zaniżenie wynagrodzenia, wyzysk cudzej pracy, przywłaszczenie cudzych dzieł, zignorowanie dorobku itp. W tym kontekście znajduje zastosowanie pojęcie (nie)sprawiedliwości ${ }^{30}$. Ale to już problem wymagający oddzielnej analizy ${ }^{31}$.

\section{Polityczny kontekst poziomów uczestnictwa}

Każdy z tych poziomów uczestnictwa - uczestnictwa w czymkolwiek (w życiu rodzinnym, w działalności gospodarczej, kulturalnej, sportowej, we wspólnocie religijnej) jest przedmiotem politycznej regulacji, a nawet politycznego zaprogramowania. Tak jest w każdym ustroju politycznym, choć oczywiście różnią się one zakresem regulacji i kontroli różnych sfer życia (m.in. rozgraniczeniem lub zatarciem granicy i charakterem współzależności między sferą życia intymnego, prywatnego oraz publicznego) oraz formami nacisku wywieranego na obywateli czy poddanych. I tak:

- Wyznaczanie miejsca i regulacja statusu uczestników to oddziaływanie polityczne, brzemienne w konflikty, uwikłane w zjawiska panowania, hierarchii społecznych, dominacji, ucisku, wyzysku, dyskryminacji i w procesy emancypacji. Nawet uznanie tożsamości i godności, dystrybucja prestiżu jest uwarunkowana politycznie. Dotyczy to zarówno klas społecznych, warstw i stanów, jak ras, grup etnicznych, kategorii płci i wieku. Co więcej, to polityczne rozstrzygnięcia przesądzają o prawie do życia określonych kategorii społecznych ${ }^{32}$.

${ }^{30}$ Zob. Z. Ziembiński, O pojmowaniu sprawiedliwości, Lublin 1992; Efektywność a sprawiedliwośćc, red. J. Wilkin, Warszawa 1997.

${ }^{31}$ Zarys tego problemu - dysproporcji między „dawaniem” (wnoszeniem) a „braniem” - przedstawił lapidarnie, lecz celnie autor minitraktatu: L. Ostasz, Etyka elementarno-uniwersalistyczna w zarysie, Kraków 1991, s. 48-49.

${ }^{32}$ Do tego odnosi się koncepcja biowładzy: M. Foucault, Trzeba bronić społeczeństwa. Wyktady w Collège de France, 1976, Warszawa 1998. 
- Przydział dóbr ze względu na status to korelat stosunków politycznych, w szczególności określonego modelu ustrojowego (społeczeństwo i państwo zhierarchizowane lub podlegające egalitaryzacji; rządy reprezentatywne i kontrolowane społecznie lub arbitralne; ustrój zakładający maksymalizację i powszechność uczestnictwa lub selektywne wykluczenie, marginalizację, dyskryminację określonych kategorii społecznych; usankcjonowanie lub zwalczanie stosunków wyzysku i ucisku).

- Mechanizm wnoszenia wkładu w funkcjonowanie społeczeństwa, gospodarki, państwa także zdeterminowany jest przez polityczne sterowanie ze strony podmiotów władzy i panowania. Wkład ten może być wnoszony dobrowolnie, pod wpływem podstępu lub pod przymusem - co zależy od ustroju państwa, panującej ideologii oraz stylu rządzenia. To państwo - zgodnie z wolą i interesem sił w nim dominujących - określa, kto jest zobowiązany do pracy, walki, kto jest uprawniony do dyscyplinowania innych. Praca może więc być pracą najemną lub niewolniczą, może być zaszczytem lub karą. Poświęcenie może być - w skali powszechnej - samoograniczeniem dobrowolnym, choć nagradzanym symbolicznie, lub wyrzeczeniem narzuconym przymusem albo przemocą.

- Ocena wkładu i dystrybucja nagród/kar to problem polityczny (ideologiczny, ustrojowy), uwikłany w spory o kryteria (nie)sprawiedliwości społecznej (por. klasyczne dylematy: według potrzeb? według zasług? według społecznej niezbędności samego uczestnika? według pozycji hierarchicznej? odpowiednio do własnej zapobiegliwości zainteresowanych? ${ }^{33}$ ).

Dotychczas mowa była o obiektywnych wyznacznikach uczestnictwa. Subiektywnym korelatem uczestniczenia w funkcjonowaniu takiej czy innej wspólnoty jest to, czy członkowie tej wspólnoty uświadamiają sobie własną przynależność oraz to, jak postrzegają i rozumieją swoje miejsce we wspólnocie, swoją rolę (funkcję, zadania, wpływ), jak się odnoszą do swego wyobrażenia i odczuć wynikających z postrzeganego stanu rzeczy. Syntetycznym tego wyrazem jest poczucie uczestnictwa.

\section{Poczucie uczestnictwa - istota i komponenty}

Na to, co nazwać można poczuciem uczestnictwa, składają się cztery czynniki.

Po pierwsze, świadomość samego faktu bycia elementem danej całości (wiedza, wyobrażenia, samowiedza i samookreślenie - kim jestem, a ściślej: za kogo się uważam w tym, w czym jestem obecny).

${ }^{33}$ Zob. H. Peyton Young, Sprawiedliwy podziat, Warszawa 2003; J. Rawls, Teoria sprawiedliwości, Warszawa 2009. 
Po drugie, ocena tego faktu (przez pryzmat mniej lub bardziej adekwatnych wyobrażeń i odczuć, gdyż możliwa jest również tzw. fałszywa świadomość, przynależność urojona), która mieści się w skali „aprobata, obojętność lub dezaprobata" - z punktu widzenia własnych potrzeb, interesów, wyznawanych zasad i przekonań, pragnień, tęsknot danej jednostki lub grupy.

Po trzecie, wynikające $\mathrm{z}$ tej diagnozy i oceny własnej sytuacji zamiary - intencja uczestnictwa lub uwolnienia się od niego, skoro jest już świadome; ukierunkowanie własnych wysiłków: na rzecz wspierania całości, na rzecz wybiórczego własnego przystosowania i przetrwania, na rzecz wyłączenia siebie, na rzecz zwalczania i zmiany.

Po czwarte, towarzyszące tym zamiarom i planom życiowym kalkulacje - co mam do zyskania, a co do stracenia pozostając w danej wspólnocie lub usiłując ja opuścić ${ }^{34}$; bilans kosztów własnego uczestnictwa biernego, jak i aktywnego, polegającego na podejmowaniu wysiłków, wnoszeniu własnego wkładu.

Poczucie uczestnictwa jest silnie skorelowane, ale nietożsame z poczuciem podmiotowości ${ }^{35}$.

Nie od rzeczy będzie pamiętać, iż tak pojęte poczucie uczestnictwa jest jakością stopniowalną: do uczestnictwa (i do jego konsekwencji w postaci zobowiązań, powinności, obowiązków, współodpowiedzialności itd.) można poczuwać się w mniejszym lub większym stopniu, i przy tym - mniej lub bardziej spójnie i konsekwentnie.

\section{Stereotypowe rozumienie poczucia uczestnictwa}

W myśleniu potocznym, które jednak może udzielać się również badaczom partycypacji, już samo słowo „poczucie uczestnictwa” kojarzy się pozytywnie. W tym obiegowym ujęciu poczucie uczestnictwa miałby tylko ten, kto akceptuje ten fakt, znajduje w nim powód do satysfakcji i motywację do podtrzymania swego uczestnictwa własnymi wysiłkami, osiągnięciami, zasługami dla wspólnoty. Co najwyżej rozumie się, iż brak tak rozumianego poczucia uczestnictwa nie oznacza jeszcze nieuczestnictwa (niebycia uczestnikiem), np. deklarowanie apolityczności nie wyłącza realnie jednostek i grup społecznych z uczestnictwa w życiu politycznym. Wyraża to już potoczne popularne porzekadło: ,jeśli nawet ty nie interesujesz się polityką, to i tak polityka interesuje się tobą".

34 Por. A. Hirschman, Lojalność, krytyka, rozstanie. Reakcje na kryzys państwa, organizacji i przedsiębiorstwa, Kraków 1995.

${ }^{35}$ Zob. K. Korzeniowski, Poczucie podmiotowości - alienacji politycznej. Uwarunkowania psychospoleczne, Poznań 1991. 
Według tego potocznego kryterium ogół uczestników miałby dzielić się po prostu na tych, którzy mają poczucie uczestnictwa i tych, którzy go nie mają, a radykalnym zaprzeczeniem i przeciwieństwem poczucia uczestnictwa miałoby być poczucie nieuczestniczenia, a przynajmniej wyobcowania. Zatem: jeśli ktoś czuje się wyobcowany, to nie może mieć poczucia uczestnictwa, i odwrotnie. To jednak - w przypadku samych ludzi, którzy czują się wyłączeni, nieobecni w danej strukturze - złudzenie, myślenie życzeniowe. A w przypadku badaczy to błąd metodologiczny.

Poczucie wyobcowania lub wręcz poczucie nieuczestniczenia to, wbrew pozorom, jedynie... szczególna forma poczucia uczestnictwa. Jeśli czuję się przymuszony, zniewolony i przynajmniej wewnętrznie zbuntowany, znaczy to, iż „nie jest mi wszystko jedno", a mój opór wymaga oceny tego, co przypada mi w udziale, co sam muszę lub mogę czynić, a więc ma za przesłankę rozpoznanie reguł danego systemu, świadomą adaptację do niesprzyjających okoliczności i stosunków społecznych. A we własnym postępowaniu podmiot rozróżnia to, co jest przystosowaniem, to, co jest unikiem, wykrętem, próbą samowyłączenia i to, co ma być formą oporu lub wręcz buntu. Trudno nie uznać buntu za specyficzny przejaw poczucia uczestnictwa, choć pod znakiem sprzeciwu, w dążeniu do zmiany lub wyrwania się z danej zależności i przynależności ${ }^{36}$. W tym sensie najżarliwsi nawet kontestatorzy panującego porządku, radykalni opozycjoniści lub separatyści mają - choć negatywnie zabarwione i ukierunkowane, i sami by tego tak nie nazwali - poczucie uczestnictwa.

Bardziej złożone jest poczucie uczestnictwa w skrajnym stanie apatii, która jest czymś więcej niż indyferentyzm (nie mam zdania lub wygodnie mi nie mieć zdania) lub obojętność („wszystko mi jedno”) ${ }^{37}$, gdyż wiąże się z poczuciem bezsensu, beznadziejności. Ale i tu - choć w stopniu minimalnym - występuje poczucie uczestnictwa, skoro obywatel lub pracownik w stanie apatii musi i sam woli znać minimum swych obowiązków formalnych, narzucanych mu wymagań społecznych (np. obyczajowych), zagrożeń dla siebie, sposobów zapewnienia sobie bezpieczeństwa, przetrwania czy „świętego spokoju”. Paradoksalnie więc, jego dążenie do wyłączenia i bierności wymaga pewnego rodzaju aktywności, namysłu, wyboru. A to czyni go uczestnikiem. Podobnie więc jak marginalizacja, a nawet wykluczenie społeczne nie jest po prostu nieuczestnictwem, tak brak identyfikacji i ,izolacjonizm” jednostek lub całych grup nie oznacza po prostu braku poczucia uczestnictwa, lecz nadaje mu tylko defektywny charakter.

${ }^{36}$ Fenomenowi buntu, kontestacji poświęcone są prace: T. Paleczny, Kontestacja. Formy buntu we współczesnym społeczeństwie, Kraków 1997; idem, Bunt „nadnormalnych”, Kraków 1998; C. Sunstein, Sprzeciw w życiu społeczeństw, Warszawa 2006.

${ }^{37}$ Ciekawy portret zbiorowej apatii przedstawił swego czasu C.W. Mills. Zob. C.W. Mills, Białe kotnierzyki. Amerykańskie klasy średnie, Warszawa 1965, s. 519-520. 
Poczucie uczestnictwa jest syndromem, splotem wyobrażeń i odczuć niejednorodnych, niejednokrotnie również wzajemnie sprzecznych.

Jest to bilans odczuć i doznań ujawnionych na wielu płaszczyznach (np. satysfakcja materialna nie musi być tożsama i współmierna do moralnej, identyfikacja ideowa nie zapobiega rozczarowaniom lub poczuciu winy itd. itp.). Toteż kwalifikacja postaw ludzkich na tej płaszczyźnie musi być zniuansowana.

\section{Pozytywne a negatywne poczucie uczestnictwa}

Realistyczne ujęcie poczucia uczestnictwa uwzględnia fakt, iż istnieje nie tylko pozytywne, ale i negatywne poczucie uczestnictwa. Pozytywne polega na akceptacji samej przynależności, satysfakcji z tego powodu i identyfikacji z danym zespołem, grupą czy instytucją.

Negatywne poczucie uczestnictwa towarzyszy przynależności jednostki lub grupy do danej wspólnoty wbrew własnej woli, a nawet wbrew własnemu poczuciu tożsamości, funkcjonowaniu w tej wspólnocie zbyt wielkim kosztem (za cenę wymuszonych, lecz nieakceptowanych ograniczeń, wyrzeczeń lub strat, a także dysonansu między własnymi przekonaniami i zasadami a odstępstwami od nich). Jego korelatem jest chroniczny dyskomfort psychiczno-moralny.

Przy tym niekoniecznie jest to poczucie czysto pozytywne lub czysto negatywne. Może to być identyfikacja per saldo lub negatywny bilans w samookreśleniu - w rozstrzyganiu przez podmiot dylematu, czy czuje się uczestnikiem danej wspólnoty.

Pozytywne poczucie uczestnictwa bynajmniej nie wyklucza „łyżki dziegciu w beczce miodu", tzn. rozlicznych zawodów, rozterek, jedynie selektywnej lub warunkowej identyfikacji. Jest to sytuacja dość typowa dla osób zaangażowanych w jakąś wielką ideę, Sprawę, dla wyznawców takich czy innych religii, ideologii, doktryn, dla zwolenników przywódcy otoczonego kultem, dla członków partii lub stowarzyszeń, których oczekiwania lub poglądy i dążenia w określonych sprawach rozmijają się z kursem kierownictwa, wolą większości itp.

Tylko względnie pozytywne i selektywne (a nie integralne, tzn. całkowite, wyłączne, niepodzielne) poczucie uczestnictwa cechuje jednostki lub całe grupy, które w danej wspólnocie przeżywają dylematy tożsamości i wyboru (np. gdzie bardziej czuję się sobą i u siebie, kim i z kim wolałbym być). To z kolei sytuacja typowa dla tzw. wielouczestnictwa ${ }^{38}$ (czyli uczestnictwa w kilku nietożsamych całościach, o składzie i więziach rozłącznych lub jedynie częściowo wspólnych), zwłaszcza jeśli towarzyszy temu konflikt ról, niezgodność interesów własnych lub reprezentowanych w każdej z tych wspólnot, trudność lub niemożliwość pogodzenia obowiązków lub zobowiązań w różnych miejscach.

38 Zob. W. Makarczyk, Wspólnota uczuć i działań, Warszawa 1993, rozdz. V. 
Wreszcie, ograniczone, bo powierzchowne i także wybiórcze pozytywne poczucie uczestnictwa mają jednostki lub grupy, które gotowe są - ze względu na swoją wygodę, indywidualne czy partykularne przyzwyczajenia i taktyki przystosowania społecznego - jedynie częściowo, okazjonalnie lub deklaratywnie, rytualnie potwierdzać swym postępowaniem faktyczne wyznawanie i praktykowanie formalnie uznawanych zasad, wzorców, wartości danej wspólnoty. Nie bez powodu Stanisław Ossowski położył nacisk na różnicę między wartościami uznawanymi (wyznawanymi), deklarowanymi i realizowanymi ${ }^{39}$. W tym kontekście np. w odniesieniu do wspólnoty wiernych mowa jest np. o „niedzielnych katolikach”, o katolicyzmie selektywnym ${ }^{40}$.

$\mathrm{Z}$ drugiej strony, jednostki lub grupy, których uczestnictwo ma charakter wymuszony i sprzeczny z ich interesami lub aspiracjami albo jednostki i grupy wyobcowane niekoniecznie, nie zawsze przejawiają swoje negatywne poczucie uczestnictwa w postaci czystej, jednowymiarowej jako subiektywne poczucie nieuczestnictwa. Przykładowo, rekrut powołany do wojska wbrew swym pacyfistycznym przekonaniom lub żołnierz wcielony do armii zaborcy o tyle jednak zachowuje elementy „pozytywnego” poczucia uczestnictwa, iż uczy się dbać o własne prawa i warunki przetrwania w obcych sobie strukturach, a przy tym w warunkach wojennych widzi zależność własnego przetrwania od sukcesu tych struktur. Tylko dezercja lub bunt żołnierzy są „czystą” odmową uczestnictwa.

Ze względu na tę złożoność rachunku korzyści i strat, przekonań i wątpliwości, satysfakcji lub niezadowolenia itd. tę dychotomię (albo pozytywne, albo negatywne poczucie uczestnictwa) trzeba nie tylko zrelatywizować (jako kwalifikacje bilansowe, a nie jednoczynnikowe), ale i uzupełnić o typ pośredni, jeszcze bardziej zrelatywizowany.

Otóż wyrównany lub niemal wyrównany bilans satysfakcji i dyskomfortu z powodu świadomości i oceny własnego uczestnictwa może powodować ambiwalentne poczucie uczestnictwa (tyleż pozytywne pod jednym względem, ile negatywne pod innym względem).

\section{Ambiwalentne poczucie uczestnictwa}

Ambiwalentne poczucie uczestnictwa jest np. udziałem mniejszości narodowych, zwłaszcza gdy są zmuszone do życia w państwie obcym dla nich kulturowo i dyskryminacyjnie nastawionym. Ambiwalentne poczucie uczestnictwa

39 St. Ossowski, Dzieła, t. III - Z zagadnień psychologii społecznej, Warszawa 1967; fragment pt. Konflikty niewspótmiernych skal wartości.

${ }_{40}$ Por. dwugłos w sprawie stopnia internalizacji i praktykowania zasad wiary: R. Magryś, Kim sq katolicy selektywni?, „Nowa Res Publica” 1997, nr 3(102) oraz E. Bieńkowska, Termin nie jest dobry!, ibidem. 
mają członkowie partii politycznych przeciwstawnych ideologicznie, współdziałających jednak w koalicji ze względów taktyczno-pragmatycznych. I obywatele państwa kierujący się racją stanu, legalnością władzy oraz własnym lojalizmem, „postawą obywatelską" i konstruktywnie (a nie kontestacyjnie) rozumianym patriotyzmem - mimo odmiennych niż u rządzących preferencji ideowych i ustrojowych ${ }^{41}$. Niemożliwość pełnej identyfikacji i dyskomfort z powodu przyjętych kompromisów ideowych nie zmienia jednak faktu, że odczuwają siłę rozmaitych zobowiązań, konieczność i szansę obrony pewnych zasad i wartości w warunkach, których sami nie określali, poczuwają się do odpowiedzialności za los współobywateli i za bezpieczeństwo całego kontynentu, dostrzegają także szanse i korzyści związane z uczestnictwem w strukturach narzuconych itd. Nawet kontestacja władzy zaborców może iść w parze z przytomnym, realistycznym włączeniem się w administracyjne, ekonomiczne i kulturalne instytucje państwa zaborczego - we własnym interesie narodowym, w celu zachowania przynajmniej częściowego wpływu, możliwości obrony własnej tożsamości i praw ${ }^{42}$.

Potocznie, a zarazem metaforycznie określamy taki stan rozchwiania, dysonansu - między dumą a wstydem, satysfakcją a rozczarowaniem, pewnością a zakłopotaniem lub dezorientacją z powodu własnej przynależności i aktywności społecznej - jako „mieszane uczucia”. Co prawda, i to określenie, i pokrewne mu „bicie się z myślami” odnoszone jest nie tylko do trwałych, a niejednoznacznie przeżywanych więzi, ale również do oceny konkretnych zdarzeń, sytuacji, do przewidywań i planów, w których zderzają się ze sobą i ważą na szali przesłanki „za” oraz „przeciw”. I do tych też okoliczności - oraz specyficznego poradzenia sobie z nimi - odnosi się z kolei popularny wałęsowski aforyzm ,jestem za, a nawet przeciw".

Ambiwalentne poczucie uczestnictwa jest stanem naturalnym i poniekąd nieuniknionym, gdy realna i możliwa przynależność jest inna niż aspiracje do przynależności (więzi z konieczności i z rozsądku, a nie z wyboru); satysfakcje z uczestnictwa są „zrównoważone” (i o tyle podważone, bo zniwelowane) przez przykrości, powody do zakłopotania, skrupuły, świadomość ponoszonych strat; korzyści z uczestnictwa są zrównoważone przez straty i koszty lub potencjalnie zagrożone przez perspektywiczne wyrzeczenia i niebezpieczeństwa; nadzieje mają przeciwwagę w porównywalnie silnych obawach lub nawet obawy są większe.

Uwzględniając zaś wspomniany już fakt, iż to, co nas zachęca i to, co zniechęca do uczestnictwa (do samej przynależności lub do aktywności), może być nieporównywalne (satysfakcja i identyfikacja pod jednym względem, niezadowolenie lub zdystansowanie, wyobcowanie pod innym względem), zauważymy także,

${ }^{41} \mathrm{~W}$ analizach prawoznawczych zwykle wskazuje się trojakie przesłanki posłuchu dla władzy, przestrzegania prawa, realizacji obowiązków obywatelskich: legalizm, oportunizm, konformizm. Zob. na ten temat: Z. Ziembiński, Etyczne problemy prawoznawstwa, Wrocław 1972, s. 144-146.

${ }^{42}$ Por. np. A. Chwalba, Polacy w stużbie Moskali, Warszawa-Kraków 1999. 
iż ambiwalentne poczucie uczestnictwa może mieć też charakter asymetryczny. Na zasadzie: wprawdzie pozytywy w bilansie przeważają, ale jeden negatyw jest nie do przyjęcia - on przesądza jeśli nie o odejściu, zerwaniu, to np. o „emigracji wewnętrznej”. I podobnie: wprawdzie negatywów przynależności jest więcej, jednak pewna wartość, zasada lub pewne dobro jest od nich ważniejsze i wymaga pozostania, uczestnictwa „mimo wszystko”, ze świadomą gotowością do samopoświęcenia. Tak jest np. wtedy, gdy działacz lub przywódca kierując się lojalnością i solidarnością ze współtowarzyszami, a także w imię honoru (nie uciekam z tonącego okrętu, nie odgrywam się na „swoich”, którzy mnie nie posłuchali) broni przegranej sprawy albo niesłusznej decyzji, przed którą sam przestrzegał.

Ambiwalentne lub negatywne poczucie uczestnictwa jest typowe i poniekąd nieuniknione dla sytuacji uwikłania, polegającej na tym, iż uczestnik firmuje lub obsługuje swym działaniem również to, na co nie ma wpływu, związany jest wspólną przynależnością z ludźmi, których postawy lub sposobu działania nie akceptuje, dokonuje wyborów nie tyle ze względu na własne przekonania, poczucie słuszności, ile ze względu na konieczności, powstałe zobowiązania, uzależnienia, naciski, ,układy” w swoim środowisku, gdy podejmuje decyzje z rozsądku, choć nie z przekonania itd. ${ }^{43}$

\section{Przejawy i komponenty poczucia uczestnictwa}

Poczucie uczestnictwa to splot wielu nastawień - albo ściśle skorelowanych ze sobą, albo powiązanych w ten sposób, iż jedno pociąga za sobą inne. Prześledźmy to w odniesieniu do pozytywnego poczucia uczestnictwa, ale ze świadomością, że struktura negatywnego lub ambiwalentnego poczucia uczestnictwa jest analogiczna.

Świadomość własnego uwikłania lub tym bardziej przynależności do jakiejś wspólnoty sprawia, że podmiot uświadamia sobie swoją więź z innymi (z członkami tej samej całości, z partnerami interakcji) - a więc w mniejszym lub większym stopniu rozumie, iż jest współuczestnikiem. To uzmysławia mu, że w swym funkcjonowaniu $\mathrm{w}$ danej wspólnocie jest związany powstałymi zależnościami, zobowiązaniami i regułami określającymi formy współżycia, współdziałania.

Zrozumienie wymagań otoczenia, reguł gry (np. norm obyczajowych i zwyczajowych), wartości i zasad konstytutywnych dla danej wspólnoty, a także zrozumienie, iż jego pozycja w niej zależy od społecznej oceny jego postępowania sprawia, iż w określonych rolach, kwestiach i zadaniach powstaje w nim poczucie obowiązku

${ }^{43}$ Zob. M. Karwat, Uwikłanie jako korelat i koszt uczestnictwa, [w:] Metafory polityki 4, red. B. Kaczmarek, Warszawa 2013. 
względnie poczucie zobowiązania. Dzieje się tak zwłaszcza pod wpływem reguły wzajemności, i szczególnie wtedy, gdy ma świadomość, ile zawdzięcza całej wspólnocie lub innym jej członkom. W przypadku silnej internalizacji wartości i zasad wspólnoty kieruje nim wręcz poczucie powinności. Przypomnijmy tu w wielkim skrócie różnicę między tymi trzema czynnikami. Obowiązek jest rezultatem narzuconych i egzekwowanych wymagań - zwłaszcza w stosunkach podporządkowania. Obowiązki spełniamy zarówno w przypadku ich akceptacji, pełnego własnego przekonania o ich słuszności, jak i z konieczności, pod naciskiem. Zobowiązanie ma charakter dobrowolny (zwłaszcza to z własnej inicjatywy), ale jest dla podmiotu wiążące ze względu na stosunki wymiany (np. rozmaite uzgodnienia, umowy, transakcje) i wspomnianą regułę wzajemności. Powinność to odczuwanie pewnego rodzaju konieczności we własnych decyzjach i czynach ze względu na spowodowany internalizacją wartości swoisty ,przymus wewnętrzny”, głos sumienia, honoru itp.

Jeśli uczestnictwo $\mathrm{w}$ danej społeczności czy grupie zaspokaja potrzeby i oczekiwania danej jednostki, to taki stan powoduje nie tylko internalizację wartości grupowych, ale i silną identyfikację ze wspólnotą oraz poczucie wspólnoty ze współtowarzyszami pracy, walki, współwyznawcami wiary itp. - co przejawia się w postawie zainteresowania wspólnymi sprawami i zadaniami, zaangażowania w życie grupy, służebności oraz lojalności i solidarności w stosunku do współuczestników. Ale też w nastawieniach tej jednostki zmienia się status samego uczestnictwa. Nie jest już ono jedynie instrumentalnym warunkiem zaspokojenia takich czy innych potrzeb indywidualnych, ale staje się formą spełniania obowiązków i powinności społecznych, a zarazem wartością samą w sobie. W takim przypadku można już mówić, iż u jednostki wykształciła się samoistna potrzeba uczestnictwa (uczestnictwa samego w sobie), że jej gotowością do przynależności i aktywnością kieruje motywacja afiliacyjna - pragnienie bycia potrzebnym, użytecznym i pozostawania $\mathrm{w}$ więzi $\mathrm{z}$ danym środowiskiem, co samo $\mathrm{w}$ sobie jest już dla niej atrakcją i satysfakcją.

Te nastawienia implikują z kolei poczucie odpowiedzialności (współodpowiedzialności) za wspólnotę i współuczestników, włącznie z poczuwaniem się do odpowiedzialności, nawet winy za rozmaite błędy, niepowodzenia, występki poprzedników lub aktualnych współuczestników. Samopoczucie i rachunki sumienia danej jednostki zostają uwikłane w zbiorowy rachunek sumienia, w grupowe poczucie dumy, chwały lub zakłopotania, zawstydzenia, niesmaku, obciążenia historycznego ${ }^{44}$. To np. typowe dylematy psychiczno-moralne patrioty czy wyznawcy kościoła.

Pozytywne (przynajmniej per saldo) poczucie uczestnictwa jest możliwe, jeśli obok tego poczucia współodpowiedzialności jednostka ma poczucie wpływu

${ }^{44}$ Por. na ten temat: Z. Cackowski, Życie ludzkie. Źródło i miara wartości, Lublin 2001, eseje pt. Odpowiedzialność i uczestnictwo; Wina-odpowiedzialność i nadodpowiedzialność. 
na funkcjonowanie grupy, podejmowane decyzje i wysiłki, dokonywane zmiany. Jeśli tak jest, to doświadcza poczucia satysfakcji z powodu uczestnictwa, wyróżnienia, zaszczycenia lub dumy z tytułu swej przynależności, a naturalnym skutkiem tego jest konsekwentna wola uczestnictwa i ambicja osobistego przyczynienia się do pomyślności wspólnoty.

Niejako symetrycznie można by scharakteryzować negatywne poczucie uczestnictwa - w kategoriach braku identyfikacji, wyobcowania, chęci wyłączenia, intencji partykularnego funkcjonowania tylko na własne konto i bez zobowiązań itd.

Pedagodzy, działacze społeczni, menedżerowie i politycy dążący do mobilizacji społecznej obywateli, wyborców, odbiorców kultury itd. nie osiągną swojego celu, jeśli w swych próbach oddziaływania ograniczą się do moralistycznych apeli, administracyjnych nakazów czy marketingowych wabików, widząc w ludziach jedynie statystyczne kategorie elektoratu, grupowego targetu, określony profil konsumenta lub czytelnika itd. Zresztą, obserwacja życia politycznego potwierdza, że największe i trwałe sukcesy osiągają ci, którzy zdolni są stworzyć wspólnoty zespolone więzią emocjonalną, zbiorową i wzajemną identyfikacją, niejako w praktyce stosując elementy teorii uczestnictwa. Pozostali umieją tylko skarżyć się na nieobliczalnego (dla nich) wyborcę czy konsumenta, na „przypadkowe społeczeństwo", nie dostrzegając własnej ograniczoności w swych koniunkturalnych zagrywkach, improwizacjach, w myśleniu jak u przysłowiowych strasznych mieszczan, którzy wszystko widzą oddzielnie.

\section{Bibliografia}

Arystoteles, Polityka, Warszawa 1964.

Becker H.S., Outsiderzy. Studia z socjologii dewiacji, Warszawa 2009.

Bieńkowska E., Termin nie jest dobry!, „Nowa Res Publica” 1997, nr 3(102).

Cackowski Z., Życie ludzkie. Źródło i miara wartości, Lublin 2001.

Chwalba A., Polacy w stużbie Moskali, Warszawa-Kraków 1999.

Durkheim E., O podziale pracy społecznej, Warszawa 1999.

Evatt C., Feld B., Dawcy i biorcy, Gdańsk 2001.

Foucault M., Trzeba bronić społeczeństwa. Wykłady w Collège de France, Warszawa 1998.

Fromm E., Rewolucja nadziei. Ku uczłowieczonej technologii, Poznań 1996.

Goffman E., Analiza ramowa. Esej z organizacji i doświadczenia, Kraków 2010.

Goldhagen D.J., Gorliwi kaci Hitlera. Zwyczajni Niemcy i Holocaust, Warszawa 1999.

Górski R., Bez państwa. Demokracja uczestniczaca w działaniu, Kraków 2007.

Grant A., Dawaj i bierz, Warszawa 2014.

Gulczyński M., Alternatywne orientacje w politologii, „Wyższa Szkoła Ekonomiczna. Zeszyty Naukowe" 2009, nr 1(54).

Hirschman A., Lojalność, krytyka, rozstanie. Reakcje na kryzys państwa, organizacji i przedsiębiorstwa, Kraków 1995. 
Holmes St., Sunstein C.R., Koszt praw. Dlaczego wolność zależy od podatków, Warszawa 2003.

Karwat M., Figuranctwo jako paradoks uczestnictwa. Eseje przewrotne, Warszawa 2004.

Karwat M., Outsiderskie odmiany apolityczności, „Wyższa Szkoła Ekonomiczna, Zeszyty Naukowe" 2009, nr 1(54).

Karwat M., Polityka i apolityczność, [w:] Interpretacje polityki, red. M. Szyszkowska, Warszawa 1991.

Karwat M., Uwiktanie jako korelat i koszt uczestnictwa, [w:] Metafory polityki, red. B. Kaczmarek, Warszawa 2013.

Korzeniowski K., Poczucie podmiotowości - alienacji politycznej. Uwarunkowania psycho-spoleczne, Poznań 1991.

Krytyka Polityczna, Partycypacja. Przewodnik krytyki politycznej, Warszawa 2012.

Łukaszewski W., Szanse rozwoju osobowości, Warszawa 1984.

Magryś R., Kim sa katolicy selektywni?, „Nowa Res Publica” 1997, nr 3(102).

Meyer G., Ryszka F., Political Participation and Democracy in Poland and West Germany, Warszawa 1991.

Mider D., Partycypacja polityczna w internecie. Studium politologiczne, Warszawa 2008.

Mills C. W., Białe kotnierzyki. Amerykańskie klasy średnie, Warszawa 1965.

Misztal B., Zagadnienia społecznego uczestnictwa $i$ współdziałania. Analiza $w$ świetle teorii i badań socjologicznych, Wrocław 1977.

Modrzejewski J., Socjalizacja i uczestnictwo społeczne. Studium socjopedagogiczne, Poznań 2007.

Newcomb Th.M., Turner R.H., Converse Ph.E., Psychologia społeczna. Studium interakcji ludzkich, Warszawa 1970.

Obuchowski K., Adaptacja twórcza, Warszawa 1985.

Ossowski St., Dzieła, t. 3, Warszawa 1967.

Ostasz L., Etyka elementarno-uniwersalistyczna w zarysie, Kraków 1991.

Paleczny T., Bunt „,nadnormalnych”, Kraków 1998.

Paleczny T., Kontestacja. Formy buntu we współczesnym społeczeństwie, Kraków 1997.

Pawłowski T., Pojęcia i metody współczesnej humanistyki, Wrocław 1977.

Piwowarski Wł., Stownik katolickiej nauki społecznej, Warszawa 1993.

Podrez E., Moralne uzasadnienie tolerancji. Studium z etyki personalistycznej, Warszawa 1999.

Rawls J., Teoria sprawiedliwości, Warszawa 2009.

Rutkowiak J., Uczenie się od outsidera. Perspektywa europejskiej wspótpracy edukacyjnej, Kraków 1997.

Rybicki P., Struktura społecznego świata. Studia z teorii społecznej, Warszawa 1979.

Sartori G., Teoria demokracji, Warszawa 1994.

Sennett R., Razem. Rytuaty, zalety i zasady wspótpracy, Warszawa 2013.

Sunstein C., Sprzeciw w życiu społeczeństw, Warszawa 2006.

Szczegóła L., Bierność obywateli. Apatia polityczna w teorii demokratycznej partycypacji, Warszawa 2013.

Weber M., Polityka jako zawód i powołanie, Kraków 1998.

Wilkin J., Efektywność a sprawiedliwość, Warszawa 1997.

Wilson E. O., Socjobiologia, Poznań 2000.

Wojtyła K., Osoba i czyn oraz inne studia antropologiczne, Lublin 2000. 
Young H. P., Sprawiedliwy podział, Warszawa 2003.

Zdybicka Z.J., Analiza pojęcia partycypacji występujacego w filozofii klasycznej, „,Roczniki Filozoficzne. Filozofia Teoretyczna" 1970, t. XVIII, z. 1.

Zieleniewski J., Organizacja zespołów ludzkich, Warszawa 1976.

Ziembiński Z., Etyczne problemy prawoznawstwa, Wrocław 1972.

Ziembiński Z., O pojmowaniu sprawiedliwości, Lublin 1992.

Znamierowski Cz., Wina i odpowiedzialność, Warszawa 1957.

\section{Мирослав Карват}

\section{Участие и чувство участия. Анализ понятий}

Политологическая конвенция, основанная на том, чтобы называть участием только активное включение граждан, работников, жителей в решение общественных вопросов и оказания на них влияния - слишком узкое понимание. Адекватное понимание участия относится также к объективной принадлежности и социальной связи. Пассивность также является участием, хотя и особенной формы. Чувство участия имеет разнообразное значение. Это моет быть парадоксальным - чувство исключения, неучастия либо чувство отчужденности, или же наоборот - чувство идентификации, удовлетворения, мотивации к активности, чувство общей ответственности, возможно также чувство амбивалентности.

Ключевые слова: участие, чувство участия, внесение вклада, получение долей.

\section{Mirosław Karwat}

\section{Participation and a sense of participation: A conceptual analysis}

The political science convention of using "participation" to describe only active involvement in deciding public matters and exerting influence by citizens, employees or residents is too narrow. An adequate understanding of "participation" should be based on objective belonging to the social community. Passivity can also be a peculiar form of participation. The sense of participation has many faces. This can be - paradoxically - the feeling of exclusion, of non-participation or alienation, or, on the contrary, the identification, satisfaction, motivation for activity, shared responsibility. Finally, an individual's sense of participation may combine both of these components.

Keywords: participation, sense of participation sense, contributing, stake holding. 